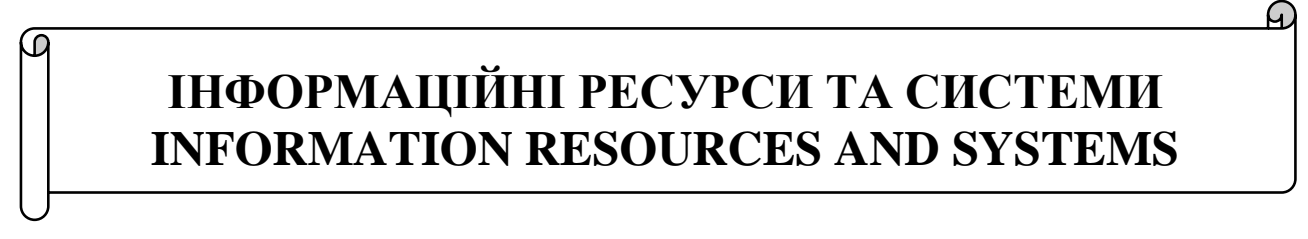

UDK 502.35:528.8

Olexandr A. Shchyptsov ${ }^{1}$, Corresponding Member of the National Academy of Sciences of Ukraine, Dr Sci. (Geogr.), Professor

ORCID ID: 0000-0002-6285-0663, e-mail: oceanography@ukr.net.

Dmitry L. Kreta ${ }^{2}, \mathrm{PhD}$, Senior Scientist

ORCID ID: 0000-0001-5897-0008,e-mail: dim.leo@gmail.com

Oleksiy G. Lebid ${ }^{2}$, PhD, Senior Researcher, Deputy Director for Science

ORCID ID: 0000-0002-4003-8068, $\boldsymbol{e}$-mail: o.g.lebid@gmail.com

Natalia A. Sheviakina ${ }^{2}, \mathrm{PhD}$, Senior Scientist

ORCID ID: 0000-0002-5984-5580e-mail: n.a.sheviakina@gmail.com

${ }^{1}$ State Institution "Scientific Hydrophysical Center of the National Academy of Sciences of Ukraine", Kyiv, Ukraine

${ }^{2}$ Institute of Telecommunications and Global Informative Space of the National Academy of Sciences of Ukraine, Kyiv, Ukraine

\title{
USE OF REMOTE SENSING RESULTS IN THE TASKS OF NAVIGATIONAL AND HYDROGRAPHIC SITUATION MONITORING
}

\begin{abstract}
The paper presents the possibilities of using modern online sources of satellite information in the tasks of monitoring the ecological and navigationalhydrographic situation and building on their basis methods and information technologies to reflect the state of marine waters and operational forecasting of changes in this state. For the tasks of monitoring the ecological and navigationalhydrographic situation, one of the most convenient and informative is the marine environment monitoring service COPERNICUS (CMEMS). This service collects and presents data on observations of spatio-temporal variability of sea water temperature and salinity values, streams parameters, etc. by using specialized artificial satellites Sentinel-1 and Sentinel-2, which intended for use in the mission of a dual satellite with high viewing frequency and high resolution. CMEMS provides, on a regular and systematic basis, information on the physical condition, variability and dynamics of the oceanic and marine ecosystems. The principle of measurement uses natural microwave emissions on the sea surface, which vary depending on the degree of roughness of the sea surface. You can get the parameters of wind direction, atmospheric water vapor, rain speed, sea ice (age, concentration and limit), the length of the snow cover and the water content in the snow.
\end{abstract}

( О.А. Щипцов, Д.Л. Крета, О.Г. Лебідь, Н.А. Шевякіна, 2020 
High-resolution ice mapping services provide ice classification and floating ice data to navies and shipping companies to ensure safe year-round shipping. The ability of the Sentinel-1 to conduct observations in any weather and during the day or night makes it ideal for accurately determining the location and movement of the vessel at sea. Oil detection applications are used to gather evidence of illegal discharges, analyze the spread of oil spills and search for oil reserves by detecting natural infiltration. Sentinel-1 marine products, in combination with global sea wave models, help determine the direction, wavelength and height of waves on the open sea, as well as help predict the weather, the movement of ships and the use of wave energy. In addition, Sentinel-1 can provide data on the interaction of ocean waves and streams, which allows you to visualize large-scale ocean streams, cold/warm water massifs, coastal streams and internal waves. Software and hardware complexes and information-analytical systems created with the use of these methods and technologies can significantly increase the efficiency and effectiveness of solving problems of environmental monitoring, navigation and hydrographic support of navigation, search and rescue operations in marine waters.

Keywords: remote sensing; ecological monitoring; space images; information technology; navigation and hydrographic situation

\title{
О.А. Щипцов ${ }^{1}$, Д.Л. Крета ${ }^{2}$, О.Г. Лебідь ${ }^{2}$, Н.А. Шевякіна ${ }^{2}$
}

${ }^{1}$ Державна установа "Науковий гідрофізичний центр Національної академії наук України", м. Київ, Україна

${ }^{2}$ Інститут телекомунікацій і глобального інформаційного простору НАН України, м. Київ, Україна

\section{ВИКОРИСТАННЯ РЕЗУЛЬТАТІВ ДИСТАНЦИЙНОГО ЗОНДУВАННЯ ЗЕМЛІ В ЗАДАЧАХ МОНІТОРИНГУ НАВІГАЦІЙНО- ГІДРОГРАФІЧНОЇ ОБСТАНОВКИ}

\begin{abstract}
Анотація. В роботі представлені можливості використання сучасних онлайн-джерел супутникової інформаиії в задачах моніторингу екологічної $i$ навігаџійно-гідрографічної обстановки та побудови на їх основі методів $i$ інформаційних технологій відображення стану морських акваторій та оперативного прогнозування змін иього стану. Для задач моніторингу екологічної $і$ навігаційно-гідрографічної обстановки однією з найбільш зручних $i$ інформативних є служба моніторингу морського середовища COPERNICUS (CMEMS). Зазначена служба COPERNICUS накопичуе та представляе дані спостережень просторово-часової мінливості значень температури та солоності морської води, параметрів течій тощо, отриманих при використанні спеціалізованих штучних супутників Землі Sentinel-1 ma Sentinel-2, що призначені для використання в рамках місї здвоєного супутника з високою частотою повторного перегляду $і$ високою роздільною здатністю. CMEMS надає на регулярній $і$ систематичній основі довідкову інформацію про фізичний стан, мінливість і динаміку океанічних $i$ морських екосистем. Принщип вимірювання використовує природні мікрохвильові викиди на поверхні моря, які варіюються в залежності від ступеня шорсткості поверхні моря. Можна отримати параметри напрямку вітру, атмосферної водяної пари, швидкості дошу, морського льоду (вік, кониентрація і межа), протяжності снігового покриву $і$ вмісту води в снігу. Послуги льодового картографування 3 високою роздільною здатністю забезпечують льодову класифікацію і дані по плавучих крижинах для берегової охорони, військово-морських флотів і судноплавних компаній для забезпечення
\end{abstract}


безпечного цілорічного судноплавства. Здатність Sentinel-1 вести спостереження в будь-яку погоду $i$ в денний або нічний час робить ї̈ ідеальною для точного визначення місиезнаходження $і$ пересування судна в морі. Додатки з виявлення нафти використовуються для збору доказів незаконних скидів, аналізу поширення нафтових розливів і пошуку нафтових запасів шияхом виявлення природного просочування. Морські продукти Sentinel-1 в поєднанні з глобальними моделями морських хвиль допомагають визначити напрямок, довжину хвиль $i$ висоту хвиль у відкритому морі, а також допомагають у прогнозуванні погоди, руху суден $i$ використанні енергії хвиль. Крім того, Sentinel-1 може надавати дані про взаємодію океанських хвиль $i$ течій, що дозволяє візуалізувати великомасштабні океанські течії, масиви холодної/теплої води, прибережні течії і внутрішні хвилі. Створені з використанням вказаних методів і технологій програмнотехнічні комплекси й інформаційно-аналітичні системи можуть істотно підвищити оперативність і результативність вирішення задач екологічного моніторингу, навігачійно-гідрографічного забезпечення судноплавства, проведення пошукових $i$ аварійно-рятувальних операчій в морських акваторіях.

Ключові слова: дистанційне зондування Землі; екологічний моніторинг; космічні знімки; інформачійні технологї; навігаційно-гідрографічна обстановка

\section{Вступ}

Увага фахівців і вчених всього світу спрямована на освоєння та управління на наукових засадах наявними ресурсами в інтересах збалансованого розвитку. У тому числі світова спільнота має реально оцінити зиски від використання екосистем морів і океанів, для чого необхідно заповнити цілу низку прогалин в наукових знаннях. Міжурядова океанографічна комісія ЮНЕСКО наразі опрацьовує програму Десятиліття (2021-2030) дослідження та ефективної експлуатації Океану.

Україна від самого початку своєї незалежності здійснювала планомірні дослідження Чорного і Азовського морів, включаючи масштабні експедиційні дослідження [1-3]. Зараз в порядку імплементації Десятиліття Океану в НАН України створено Раду з досліджень Світового океану, в програмі досліджень на 2019-2023 роки приділено значну увагу вивченню екологічної і навігаційно-гідрографічної обстановки Чорного і Азовського морів [4].

\section{Основна частина}

Аналіз численних досліджень показує, що ефективність контактних методів моніторингу поверхневих вод можна суттєво підвищити за рахунок застосування технологій дистанційного зондування Землі з космосу (ДЗ3) [5-7]. Методи Д3З в багатьох випадках виявляються більш економними, оперативними й інформативними, ніж традиційні натурні методи досліджень. Вони все ширше використовуються в самих різних сферах людської діяльності: в економіці, науковій і освітній діяльності, військовій сфері.

Стосовно завдань екологічного і навігаційно-гідрографічного моніторингу морських акваторій їх переваги полягають:

- у високій оглядовості, можливості одержання оперативної інформації про параметри стану морських акваторій на великих ділянках; 
- у можливості переходу від дискретної до безперервної картини просторового розподілу значень параметрів стану морських акваторій;

- у можливості одержання інформації про параметри стану морських акваторій у віддалених районах.

Щороку запускаються нові супутники і цілі системи (рої) супутників, їх технічні (роздільна здатність, спектральний діапазон тощо) і функціональні можливості (частота зйомки, створення стереопар тощо) невпинно ростуть. Споживачам на їх замовлення надаються як необроблені супутникові знімки, так і попередньо оброблена та дешифрована графічна інформація і навіть результати аналізу графічної інформації за обраним напрямом. Здебільшого вартість супутникової інформації достатньо висока, проте існує ряд проектів гуманітарного, наукового і освітнього спрямування, що надають супутникову інформацію (з певними обмеженнями) безкоштовно.

За результатами вивчення рейтингів авторитетних міжнародних компаній [8] та власних досліджень авторів було визначено ряд кращих на сьогоднішній день безкоштовних і платних джерел супутникової інформації, які можна використовувати для вирішення тематичних аналітичних задач:

- EarthExplorer від USGS

- LandViewer від EOS

- EO Browser i Sentinel Playground від Sentinel Hub

- Copernicus Open Access Hub

- Каталог знімків INPE

- Платформа Soar.

Для задач моніторингу екологічної і навігаційно-гідрографічної обстановки однією з найбільш зручних і інформативних є служба моніторингу морського середовища COPERNICUS (CMEMS). CMEMS базується на розподіленій моделі надання послуг [9]. Служба включає центри поширення продукції (надання послуг) двох типів: Центри моніторингу й прогнозування та Тематичні центри збирання даних TAC.

Зазначена служба COPERNICUS накопичує та представляє дані спостережень просторово-часової мінливості значень температури та солоності морської води, параметрів течій тощо, отриманих при використанні спеціалізованих штучних супутників Землі Sentinel-1 та Sentinel-2, що призначені для використання в рамках місії здвоєного супутника з високою частотою повторного перегляду і високою роздільною здатністю [10].

Завдання моніторингу морських акваторій основані на можливості реєстрації сучасною дистанційною апаратурою широкого спектру значущих параметрів водного середовища [7]. До таких параметрів відносяться, перш за все:

- гідрооптичні - варіації яких обумовлені флуктуаціями коефіціснтів розсіяння і поглинання світла при змінах концентрації в товщі води зважених i поглинаючих речовин теригенного і біологічного походжень, або наявністю поверхневих плівок, обумовлених, наприклад, нафтопродуктами;

- температурні - в областях полів течій, апвелінгу, взаємодії турбулентності і внутрішніх хвиль з водною поверхнею та ін.;

- гідроелектричні - солоність.

CMEMS надає на регулярній і систематичній основі довідкову інформацію про фізичний стан, мінливість і динаміку океанічних і морських екосистем як Світового океану, так і Європейських морів, в тому числі Чорного моря. 
Принцип вимірювання використовує природні мікрохвильові викиди на поверхні моря, які варіюються в залежності від ступеня шорсткості поверхні моря. Чим шорсткіше море, тим інтенсивніше викиди. Напрямок вітру визначається співвідношенням між горизонтальними i вертикальними поляризаційними характеристиками сигналу i анізотропним розподілом вітрових хвиль. Вектори вітру оцінюються шляхом вимірювання багаточастотних поляриметричних температур яскравості. Також можна отримати параметри атмосферної водяної пари, рідкої води з хмар, швидкості дощу, морського льоду (вік, концентрація і межа), протяжність снігового покриву і вміст води в снігу.

Послуги льодового картографування 3 високою роздільною здатністю забезпечують льодову класифікацію i дані по плавучих крижинах для берегової охорони, військово-морських флотів і судноплавних компаній для забезпечення безпечного цілорічного судноплавства в акваторіях, де з'являється льодове покриття. Для морського льоду може бути визначена інформація про концентрацію, протяжність, тип, товщину і швидкість дрейфу льоду. Можна також зібрати інформацію про місцезнаходження, розмір та дрейф окремих крижин. Дані подвійної поляризації Sentinel-1 можуть значно поліпшити класифікацію і диференціацію льоду. Завдяки виявленню змін в протяжності льодового покриття Sentinel-1 може бути використаний для оцінки впливу на навколишнє середовище, на прибережні райони і транспорт.

Sentinel-1 використовує широку зону покриття 3 поліпшеним часом повторного перегляду і здатний потенційно виявляти навіть малі за розміром кораблі (рис. 1). Здатність Sentinel-1 вести спостереження в будь-яку погоду і в денний або нічний час робить іiі ідеальною для точного визначення місцезнаходження і пересування судна в морі, що дозволяє більш ефективно і економічно використовувати інші засоби забезпечення безпеки, такі як патрульні літаки і кораблі.

Додатки 3 виявлення нафти використовуються для збору доказів незаконних скидів, аналізу поширення нафтових розливів і пошуку нафтових запасів шляхом виявлення природного просочування. Плями нафти чітко видно на знімках супутника як характерні темні смуги (рис. 2). Більшість нафтових плям викликано тим, що судна спорожнюють трюми перед входом в порт. Виявлення можуть бути співвіднесені з даними, переданими 3 суден системою автоматичної ідентифікації або системою раннього попередження і стеження для визначення джерел і судового переслідування порушників.

Дані, які стосуються моніторингу розливів нафти, передаються з супутника в режимі реального часу для прийому місцевими наземними станціями, які надають підтримку європейським i національним службам. Аналогічним чином, виявлення природних нафтових витоків 3 дна моря може дати ключ до пошуку нафти.

Sentinel-1 добре вловлює зміни шорсткості поверхні, викликані вітрами на поверхні моря. Морські продукти Sentinel-1 в поєднанні 3 глобальними моделями морських хвиль допомагають визначити напрямок, довжину хвиль $\mathrm{i}$ висоту хвиль у відкритому морі, а також допомагають у прогнозуванні погоди, руху суден і використанні енергії хвиль. Оцінки вітрових полів також відіграють важливу роль в моніторингу нафтових розливів, допомагаючи знімати сліди від реальних розливів. 


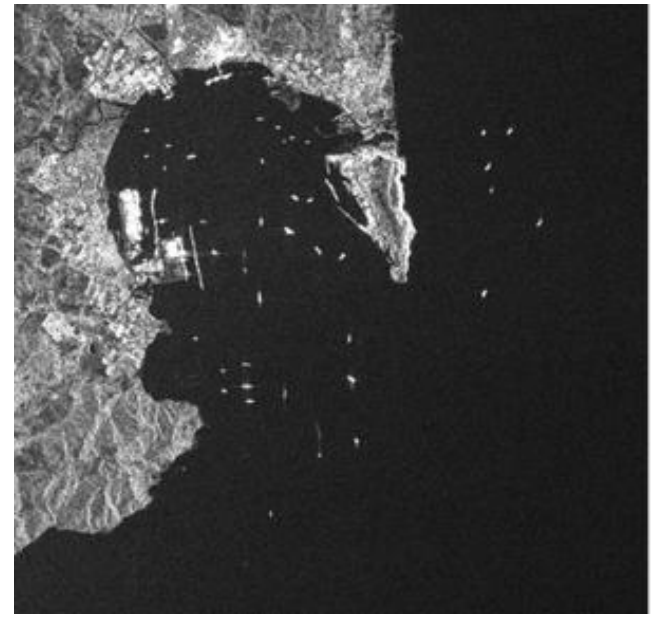

a)

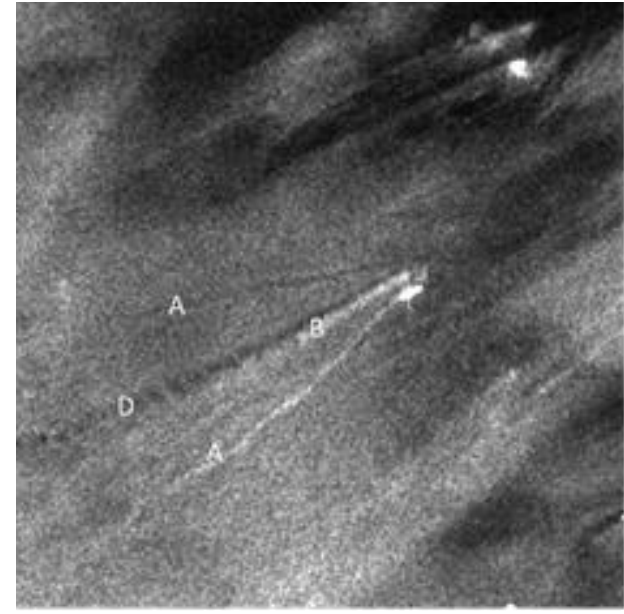

б)

Рис. 1 - Моніторинг суден на знімках Sentinel-1: а) акваторія між Гібралтаром і Альхесирасом, вересень 2017 р.; б) дальній слід за судном

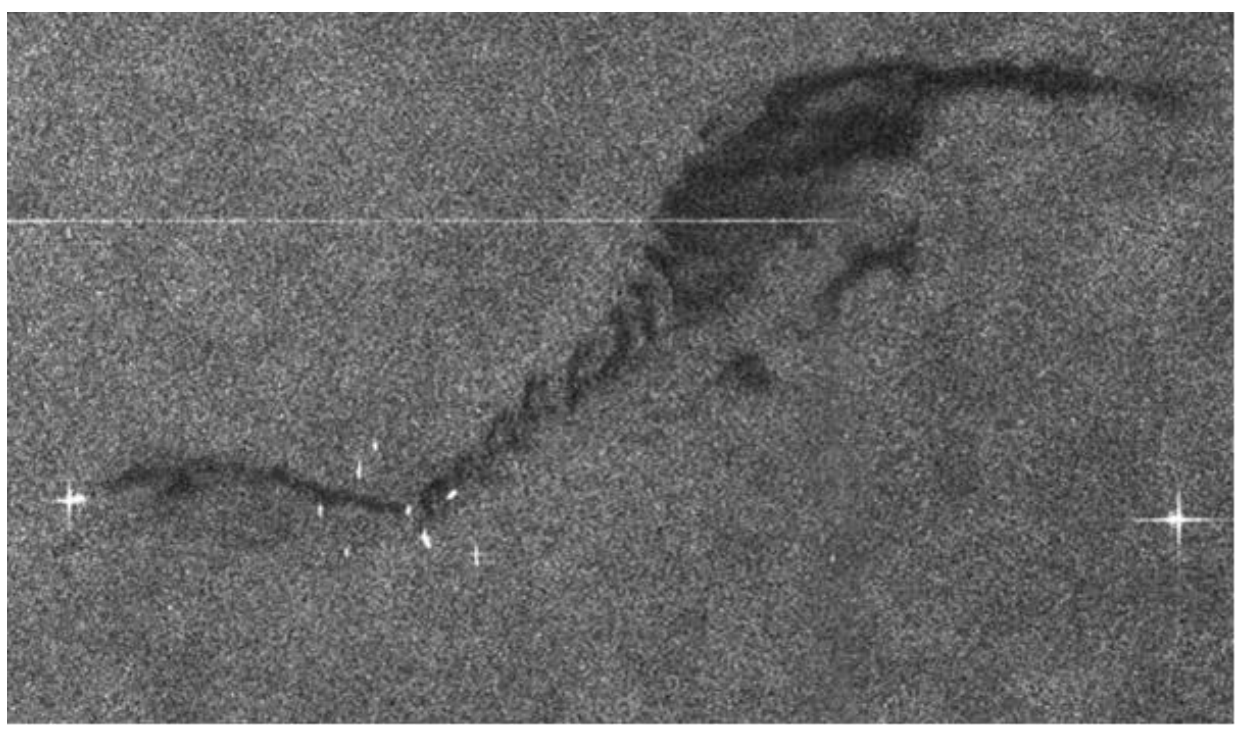

Рис. 2 - Розлив нафти, виявлений біля узбережжя Бельгії (Зебрюгге) 08.10.2015 після зіткнення двох суден

Крім того, Sentinel-1 може надавати дані про взаємодію океанських хвиль і течій, що дозволяє візуалізувати великомасштабні океанські течії, масиви холодної/теплої води, прибережні течії і внутрішні хвилі [8-10].

Дані Sentinel доступні через службу доступу до даних та інформації Copernicus (https://scihub.copernicus.eu). Для отримання доступу до даних достатньо пройти реєстрацію та увійти в службу доступу, виділити область інтересів і ввести критерії пошуку знімків (наприклад знімки видимого діапазону Sentinel-2). За результатами пошуку і вибору необхідний архів даних буде завантажений на комп'ютер користувача. Після розпаковки архіву отриманий набір файлів може бути завантажений в програму ArcGIS для подальшого використання в роботі користувача. 


\begin{tabular}{|c|c|c|c|}
\hline †Имя & Тип & Размер & Дата \\
\hline$\rightarrow[.]$. & & $\langle$ \Папка> & 19.10.2020 21:39 \\
\hline T35TQ_20201019T085909_B01 & $\mathrm{jp} 2$ & 2961689 & $19.10 .202014: 06$ \\
\hline T35TQL_20201019T085909_B02 & $\mathrm{jp} 2$ & 91244591 & $19.10 .202014: 07$ \\
\hline T35TQL_20201019T085909_B03 & $\mathrm{jp} 2$ & 89113015 & $19.10 .202014: 07$ \\
\hline T35TQL_20201019T085909_B04 & $\mathrm{jp} 2$ & 89224481 & $19.10 .202014: 07$ \\
\hline T35TQL_20201019T085909_B05 & $\mathrm{jp} 2$ & 24572027 & $19.10 .202014: 07$ \\
\hline T35TQL_20201019T085909_B06 & $\mathrm{jp} 2$ & 25173028 & $19.10 .202014: 07$ \\
\hline T35TQL_20201019T085909_B07 & jp2 & 25639536 & 19.10.2020 14:07 \\
\hline T35TQL_20201019T085909_B08 & $\mathrm{jp} 2$ & 90917886 & $19.10 .202014: 07$ \\
\hline T35TQL_20201019T085909_B8A & $\mathrm{jp} 2$ & 25992184 & $19.10 .202014: 07$ \\
\hline T35TQL_20201019T085909_B09 & $\mathrm{jp} 2$ & 2828618 & 19.10.2020 14:06 \\
\hline T35TQL_20201019T085909_B10 & $\mathrm{jp} 2$ & 1809467 & $19.10 .202014: 06$ \\
\hline T35TQL_20201019T085909_B11 & $\mathrm{jp} 2$ & 23550022 & $19.10 .202014: 07$ \\
\hline T35TQL_20201019T085909_B12 & $\mathrm{jp} 2$ & 23502194 & $19.10 .202014: 07$ \\
\hline T35TQL_20201019T085909_TCI & jp2 & 115990650 & $19.10 .202014: 08$ \\
\hline
\end{tabular}

Рис. 3 - Набір файлів в завантаженому архіві Sentinel-2

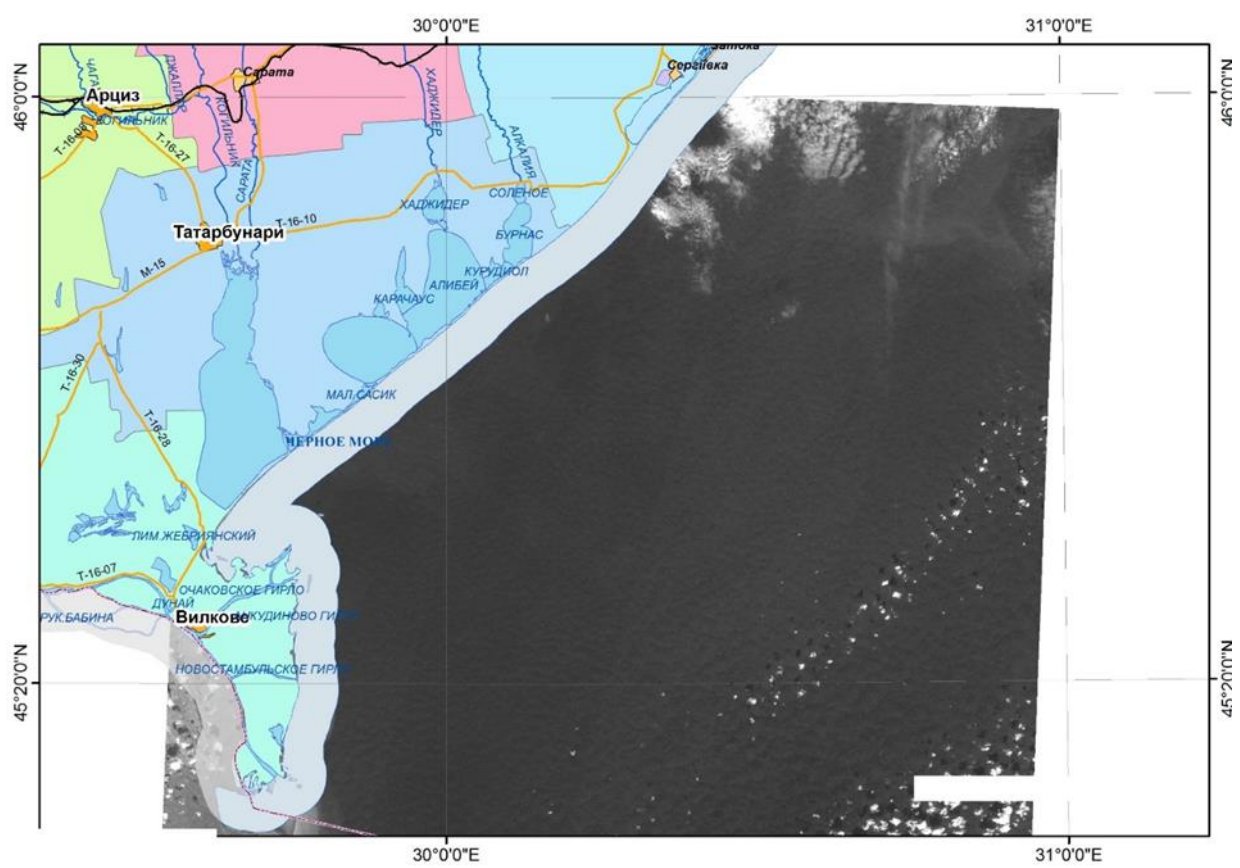

Рис. 4 - Вигляд завантаженого архіву Sentinel-2 в програмі ArcGIS

Тестування швидкодії завантаження було проведено на реальному архіві даних, що має розмір 631 Мб. Час завантаження склав близько 6 хв. при пропускній здатності інтернет-каналу користувача 100 Мб/с. На рис. 3 представлена комплектність файлів в архіві, на рис. 4 - відображення вмісту архіву засобами програми ArcGIS.

Відомі аналоги проблемно-орієнтованих ГІС [11-12] уже продемонстрували високу ефективність їх застосування при вирішенні широкого кола завдань охорони природи й управління природокористуванням для оптимізації екологічної ситуації в акваторії Чорного моря. 
Структура інформаційного фонду ГІС визначається характером i предметною спрямованістю прикладних завдань, реалізованих в і1ї складі. При цьому передбачене застосування нових завдань у визначенні закономірностей взаємодії систем і об'єктів. Геомодель місцевості й водних акваторій повинна складатися згідно 3 наявним картографічним матеріалом, державною статистичною інформацією, окремими вимірами і спостереженнями за результатами натурних досліджень та представляється:

- у растровому форматі у вигляді растрових зображень космічної інформації (поточної й минулих років) і оцифрованих тематичних карт;

- у векторному форматі у вигляді тематичних шарів у середовищі ArcGIS;

- у текстовому форматі у вигляді таблиць бази даних тематичної й статистичної інформації;

- у графічному виді у вигляді діаграм, графіків, символів легенд.

Використання геоінформаційних технологій забезпечує можливості відображення стану акваторій морів та прогнозування на їх основі змін стану, оскільки візуалізацією геопросторових даних засобами ГІС забезпечується гармонізація безлічі структур баз даних у єдине, об'єктно-орієнтоване інформаційне поле. При цьому простота наочного подання даних поєднується зі складністю побудови запитів при формуванні багаторівневої структури підтримки прийняття рішень.

\section{Висновки}

Описані методи і технології одержання, відбору, зберігання і передачі параметрів гідрофізичних полів, дистанційно виміряних в морських акваторіях 3 використанням спеціалізованих штучних супутників Землі, можуть ефективно використовуватись для моніторингу екологічної і навігаційногідрографічної обстановки в морських акваторіях, а у поєднанні із засобами прогнозного моделювання - для побудови оперативних прогнозів змін морської обстановки.

Для одержання параметрів гідрофізичних полів та іншої графічної інформації можуть бути використані розглянуті безкоштовні онлайн-сервіси, зокрема служба моніторингу морського середовища COPERNICUS. У окремих випадках для отримання додаткової інформації може виникнути необхідність використання накопичених у профільних установах і організаціях (Державне космічне агентство України та ін.) платних знімків і отриманої на їх основі інформації або ж придбання нових знімків і інформації.

Запропонований процес отримання оперативних океанографічних даних відповідає рекомендаціям i практикам програми «Міжнародний обмін океанографічними даними та інформацією» МОК ЮНЕСКО. Зазначені онлайн-сервіси надають, зокрема, гідрофізичні поля й інші гідрофізичні параметри, отримані шляхом розрахунку за певними математичними моделями на підставі первинних даних супутникових знімків. При практичному використанні вказаних гідрофізичних полів і параметрів необхідно здійснювати періодичну верифікацію розрахункових даних шляхом здійснення аналізу характеристик та вибору технічних засобів вивчення морського середовища і проведення відповідних експедиційних досліджень. 
Створені 3 використанням описаних методів і технологій програмнотехнічні комплекси й інформаційно-аналітичні системи можуть істотно підвищити оперативність і результативність вирішення задач екологічного моніторингу, навігаційно-гідрографічного забезпечення судноплавства, проведення пошукових i аварійно-рятувальних операцій в морських акваторіях.

\section{СПИСОК ЛІЕРАТУРИ}

1. Комплексные экспедиционные исследования 4-го рейса НИС «Киев» / Щипцов А.А., Шнюков Е.Ф., Коболев В.П., Лебедь А.Г. // Геофиз. журн. 1996. Т. 18, № 4, С. 83-84.

2. Геология Черного моря. (По результатам геологических и геофизических исследований 5-го рейса НИС «Киев») / Шнюков Е.Ф., Коболев В.П., Стажилов А.Г. и др. - Киев: ОМГОР ННПМ Украины, 1997. - 188 с.

3. Геология, геофизика и гидрография северо-западной части Черного моря / Е.Ф. Шнюков, А.В. Иванников, В.П. Коболев - Киев: Изд-во Государственной гидрографической службы Украины, 1998. - 221 с.

4. Щипцов О.А. Морські дослідження в Україні і світі. Наука про океан у наступному Десятилітті / О.О. Щипцов. О.А. Щипцов // Океанографічний журнал (Проблеми, методи та засоби досліджень Світового океану), 2019. - №1. - С. 6-26.

5. Красовський Г.Я. Космічний моніторинг безпеки водних екосистем із застосуванням геоінформаційних технологій. - К.: Інтертехнологія, 2008. - 480 с.

6. Моніторинг навколишнього середовища 3 використанням космічних знімків супутника NOAA / [О.М. Трофимчук, В.В. Радчук, Г.Я. Красовський, І.В. Радчук] // Під ред. С.О. Довгого. - К., ФОП Пономаренко Є.В., 2013, 316 с.

7. Сучасні інформаційні технології екологічного моніторингу Чорного моря / [С.О. Довгий, Г.Я. Красовський, В.В. Радчук, О.М. Трофимчук та інші] // Під ред. С.О. Довгого. - К., 2010, 260 с.

8. Geospatial world. 2020 report. Available online: https://www.geospatialworld.net

9. USGS science for a changing world. 2020. Available online: https://earthexplorer.usgs.gov

10. A complete archive of Sentinel-1, Sentinel-2, Sentinel-3, Sentinel-5P, ESA's archive of Landsat 5, 7 and 8, global coverage of Landsat 8, Envisat Meris, MODIS, Proba-V and GIBS products in one place. Available online: https://apps.sentinel-hub.com/eo-browser

11. The aspects of using GIS in monitoring of environmental components // O. Trofymchuk, V. Klymenko, Y. Anpilova, N. Sheviakina, S. Zahorodnya / International multidisciplinary scientific geoconference SGEM 2020 - Albena, Bulgaria, 16-25 August, 2020, P. 581-588.

12. Remote Sensing Monitoring of Biotopes Distribution within Nature Reserve Area // O. Trofymchuk, S. Zahorodnya, N. Sheviakina, I. Radchuk, O. Tomchenko / Journal of Environmental Research, Engineering and Management. - 2020, Vol. 76, No. 3. - pp. 109120.

Стаття надійшла до редакиії 25.05.2020 і прийнята до друку після рецензування 15.09.2020

\section{REFERENCES}

1. Shhipcov, A.A., Shnjukov, E.F., Kobolev, V.P., \& Lebed', A.G. (1996). Kompleksnye jekspedicionnye issledovanija 4-go rejsa NIS «Kiev» [Complex expeditionary research of the 4th cruise of the NIS "Kiev"]. Geofiz. zhurn., 18 (4), 83-84. (in Russian) 
2. Shnjukov, E.F., Kobolev, V.P., Stazhilov, A.G. et al. (1997). Geologija Chernogo morja. (Po rezul'tatam geologicheskih i geofizicheskih issledovanij 5-go rejsa NIS «Kiev») [Geology of the Black Sea. (Based on the results of geological and geophysical studies of the 5th cruise of the NIS Kiev)]. Kiev: OMGOR NNPM Ukrainy. (in Russian)

3. Shnjukov, E.F., Ivannikov, A.V., \& Kobolev, V.P. (1998). Geologija, geofizika $i$ gidrografija severo-zapadnoj chasti Chernogo morja [Geology, geophysics and hydrography of the northwestern part of the Black Sea]. Kiev: Izd-vo Gosudarstvennoj gidrograficheskoj sluzhby Ukrainy. (in Russian)

4. Shchyptsov, O.A., \& Shchyptsov, O.O. (2019). Morski doslidzhennia v Ukraini i sviti. Nauka pro okean u nastupnomu Desiatylitti [Marine research in Ukraine and the world. The science of the ocean in the next decade]. Okeanohrafichnyi zhurnal (Problemy, metody ta zasoby doslidzhen Svitovoho okeanu), 1, 6-26. (in Ukrainian)

5. Krasovskyi, H.Ia. (2008). Kosmichnyi monitorynh bezpeky vodnykh ekosystem iz zastosuvanniam heoinformatsiinykh tekhnolohii [Space monitoring of aquatic ecosystem safety with the use of geoinformation technologies]. K.: Intertekhnolohiia. (in Ukrainian)

6. Trofymchuk, O.M., Radchuk, V.V., Krasovskyi, H.Ia., \& Radchuk, I.V. (2013). Monitorynh navkolyshnoho seredovyshcha $z$ vykorystanniam kosmichnykh znimkiv suputnyka NOAA [Environmental monitoring using NOAA satellite imagery]. S.O. Dovhyi (Ed.). K.: FOP Ponomarenko Ye.V. (in Ukrainian)

7. Dovhyi, S.O., Krasovskyi, H.Ia., Radchuk, V.V., Trofymchuk, O.M. et al. (2010). Suchasni informatsiini tekhnolohii ekolohichnoho monitorynhu Chornoho moria [Modern information technologies of ecological monitoring of the Black Sea]. S.O. Dovhyi (Ed.). Kyiv. (in Ukrainian)

8. Geospatial world. 2020 report. Retrieved from: https://www.geospatialworld.net

9. USGS science for a changing world. (2020). Retrieved from: https://earthexplorer.usgs.gov

10. A complete archive of Sentinel-1, Sentinel-2, Sentinel-3, Sentinel-5P, ESA's archive of Landsat 5, 7 and 8, global coverage of Landsat 8, Envisat Meris, MODIS, Proba-V and GIBS products in one place. Retrieved from: https://apps.sentinel-hub.com/eo-browser

11. Trofymchuk, O., Klymenko, V., Anpilova, Y., Sheviakina, N., \& Zahorodnya, S. (2020). The aspects of using GIS in monitoring of environmental components. In Proc. International multidisciplinary scientific geoconference SGEM 2020 (Albena, Bulgaria, 16-25 August, 2020).(pp. 581-588).

12. Trofymchuk, O., Zahorodnya, S., Sheviakina, N., Radchuk, I., \& Tomchenko, O. (2020). Remote Sensing Monitoring of Biotopes Distribution within Nature Reserve Area. Journal of Environmental Research, Engineering and Management, 76 (3), 109-120.

The article was received 25.05.2020 and was accepted after revision 15.09.2020

\section{Щипцов Олександр Анатолійович}

член-кореспондент НАН України, доктор географічних наук, професор, директор Державної установи "Науковий гідрофізичний центр Національної академії наук України"

Адреса робоча: Україна, м. Київ, пр. Академіка Глушкова, 42

ORCID ID 0000-0002-6285-0663 e-mail: oceanography@ukr.net.

\section{Крета Дмитро Леонідович}

кандидат технічних наук, старший науковий співробітник відділу природних ресурсів Інституту телекомунікацій і глобального інформаційного простору Національної академії наук України

Адреса робоча: 03186 Україна, м. Київ, Чоколівський бульвар, 13

ORCID ID 0000-0001-5897-0008 e-mail: dim.leo@gmail.com 


\section{Лебідь Олексій Григорович}

кандидат технічних наук, старший дослідник, заступник директора 3 наукової роботи Інституту телекомунікацій і глобального інформаційного простору Національної академії наук України

Адреса робоча: 03186 Україна, м. Київ, Чоколівський бульвар, 13

ORCID ID 0000-0002-4003-8068 e-mail: o.g.lebid@gmail.com

\section{Шевякіна Наталя Анатоліївна}

кандидат технічних наук, старший науковий співробітник відділу досліджень навколишнього середовища Інституту телекомунікацій і глобального інформаційного простору Національної академії наук України

Адреса робоча: 03186 Україна, м. Київ, Чоколівський бульвар, 13

ORCID ID 0000-0002-5984-5580 e-mail: n.a.sheviakina@ gmail.com 